\title{
BIOMASS, VIRUS CONCENTRATION, AND SYMPTOMATOLOGY OF CUCURBITS INFECTED BY MILD AND SEVERE STRAINS OF Papaya ringspot virus
}

\author{
Davi Andrade Pacheco ${ }^{1}$; Jorge Alberto Marques Rezende ${ }^{*}$; Sônia Maria de Stefano Piedade ${ }^{2}$ \\ ${ }^{I}$ USP/ESALQ - Depto. de Entomologia, Fitopatologia e Zoologia Agrícola - C.P. 9 - 13418-900 - Piracicaba, SP - \\ Brasil. \\ ${ }^{2}$ USP/ESALQ - Depto. de Ciências Exatas. \\ *Corresponding author <jamrezen@esalq.usp.br>
}

\begin{abstract}
Pre-immunization with mild strains of Papaya ringspot virus - type W (PRWV-W) has allowed the mosaic disease to be controlled in different cucurbit species, with increases in marketable fruit yield. The objective of this study was to compare virus concentration, biomass and symptomatology of 'Caserta' zucchini squash, 'Menina Brasileira' long-neck squash and 'Crimson Sweet' watermelon plants infected by three mild strains and one severe strain of PRSV-W. Plants were inoculated at the cotyledonary stage, under greenhouse conditions, sampled at 7, 14, 21, 28 and 35 days after inoculation (DAI), and analyzed by PTA-ELISA. The severity of the symptoms was scored according to a scale from 1 to 5 , and the fresh and dry biomass of the aerial part of the plants were evaluated at 40 DAI. Concentrations of the mild strains, based on absorbance values of the PTA-ELISA, were lower than the concentration of the severe strain for all species. The mild strains did not cause mosaic in infected plants of all species. Plants of zucchini squash and watermelon infected by the severe strain exhibited severe mosaic symptoms, but the same was not noticed for infected long-neck squash plants. Biomass values from zucchini squash and watermelon plants infected by the mild strains were $1.7 \%$ to $12.4 \%$ lower as compared to healthy plants. Biomass values of zucchini squash and watermelon plants infected by the severe strain presented greater reduction, varying from $29 \%$ to $74 \%$. However, biomass values of long-neck squash plants infected by the mild and severe strains were similar for all treatments.
\end{abstract}

Key words: PTA-ELISA, Cucurbita pepo, Cucurbita moschata, Citrullus lanatus

\section{BIOMASSA, CONCENTRAÇÃO VIRAL E SINTOMATOLOGIA DE CUCURBITÁCEAS INFECTADAS POR ESTIRPES FRACAS E SEVERA DO Papaya ringspot virus}

\begin{abstract}
RESUMO: A premunização com estirpes fracas do Papaya ringspot virus - type W (PRSV-W) tem proporcionado o controle do mosaico em diferentes cucurbitáceas, com ganhos na produção de frutos comerciais. Neste trabalho foram comparadas as concentrações virais, severidade dos sintomas e biomassa das plantas de abobrinha-de-moita 'Caserta', de abóbora 'Menina Brasileira' e de melancia 'Crimson Sweet' infectadas com três estirpes fracas e uma estirpe severa do PRSV-W. As plantas foram inoculadas em estádio cotiledonar e mantidas em casa de vegetação. Aos 7, 14, 21, 28 e 35 dias após a inoculação (DAI), amostras foliares foram analisadas por PTA-ELISA para avaliar a concentração viral. A severidade dos sintomas foi avaliada por uma escala de notas de 1 a 5 e a biomassa da parte aérea das plantas foi determinada aos 40 DAI. As concentrações das estirpes fracas foram menores do que a da estirpe severa nas três espécies. As estirpes fracas não causaram sintomas de mosaico nas plantas das três espécies estudadas. A estirpe severa causou sintomas extremamente acentuados em abobrinha-de-moita e melancia e sintomas relativamente fracos em abóbora 'Menina Brasileira'. Os valores de biomassa das plantas de abobrinha-de-moita e melancia infectadas pelas estirpes fracas sofreram reduções que variaram de $1,7 \%$ a 12,4 \%, quando comparados aos das plantas sadias. Quando infectadas com a estirpe severa, as reduções na biomassa variaram de $29 \%$ a $74 \%$. Os valores de biomassa da abóbora 'Menina Brasileira' infectada com as estirpes fracas e severa foram equivalentes aos das plantas sadias.

Palavras-chave: PTA-ELISA, Cucurbita pepo, C. moschata, Citrullus lanatus
\end{abstract}

\section{INTRODUCTION}

The family Cucurbitaceae comprises approxi- mately 80 genera and over 800 species of plants. Among these, many have great worldwide economical value as horticulture food. In Brazil, the species of greatest eco- 
nomic expression belong to the genera Cucurbita (pumpkin, zucchini squash and winter squash), Cucumis (cucumber, melon and West Indian gherkin), Citrullus (watermelon), Sechium (chayote) and Lagenaria (bottle gourd).

The cucurbits are in general subject to several virus-caused diseases, such as the zucchini yellow mosaic, caused by the Zucchini yellow mosaic virus (ZYMV), and zucchini lethal chlorosis, caused by the Zucchini lethal chlorosis virus (ZLCV), among others. In addition to these, a virus disease commonly known in the field as zucchini squash mosaic, watermelon mosaic or melon mosaic depending on the plant species it attacks (Yuki, 1990), causes severe reductions in leaf area, fruit development and yield, and has been considered as one of the most important cucurbit diseases. The disease is caused by the species Papaya ringspot virus - type Watermelon (PRSV-W), in the genus Potyvirus (Purcifull et al., 1984).

It is quite difficult to control the mosaic caused by PRSV-W, due to the absence of resistant cultivars in most cultivated species and to inefficient control of vector aphids by chemical or cultural measures. In view of this, research projects were started in the 1990's in order to study the practical and economical viability of pre-immunizing plants with mild strains of PRSV-W as a control alternative for this disease. Tests with zucchini squash (Cucurbita pepo, L.) cv. Caserta, long-neck squash (Cucurbita moschata Duch.) cv. Menina Brasileira and hybrid Tetsukabuto-type pumpkin (C. maxima Duch. ex Lam x C. moschata Duch.) plants showed that pre-immunization was efficient in controlling mosaic under greenhouse and field conditions (Dias \& Rezende, 2000; Rezende \& Pacheco, 1998; Rezende et al., 1999). This technology is already in use, at a small scale, to control this virus disease in commercial plantings, allowing significant yield gain. Despite the fact that a reduction in final yield of pre-immunized plants is known to happen and is even understandable (Dias \& Rezende, 2000; Rezende \& Pacheco, 1998), no specific reports exist on the effect of mild strains on the biomass of plants, nor on their concentration in infected tissues. In view of this, the objectives of the present work were to evaluate the concentration of mild and severe strains of PRSV-W in extracts of infected tissues of 'Caserta' zucchini squash, 'Menina Brasileira' long-neck squash and 'Crimson Sweet' watermelon (Citrullus lanatus (Thunb.) Matsum. \& Nakai) plants at different intervals after inoculation, and to evaluate symptoms and biomass in these plants 40 days after inoculation.

\section{MATERIAL AND METHODS}

Test-plants, virus strains and mechanical inoculation

This research utilized the following species: zucchini squash cv. Caserta, long-neck squash cv. Menina
Brasileira, and watermelon cv. Crimson Sweet. All plants were maintained under greenhouse conditions in

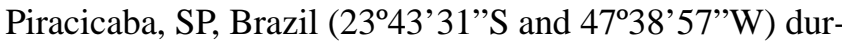
ing the entire duration of the experiment.

Plants were seeded on styrofoam trays with 128 cells containing organic substrate previously added to the cells. Upon reaching the cotyledonary stage, plants were individually transferred to $16 \mathrm{~cm}$ tall sterilized cylindrical aluminum pots, with a diameter of $14.5 \mathrm{~cm}$, filled with a mixture of soil, cattle manure and sand at a 2:1:1 proportion, previously prepared and autoclaved for 2 hours at $121^{\circ} \mathrm{C}$. Two experiments were performed in different seasons; experiment I in January and February and experiment II in June and July / 2001.

Two PRSV-W mild strains, referred to as PRSVW-1 and PRSV-W-2, selected by Rezende et al. (1994) from blisters on zucchini squash leaf showing mosaic, one mild strain selected from blisters on watermelon leaf showing mosaic, referred to as PRSV-W-3 (data not published) and one strain from the regular (severe) complex, collected in zucchini squash leaves in the Campinas (SP) region, referred to as PRSV-W-C, were utilized.

The strains were maintained separately on 'Caserta' zucchini squash plants, under greenhouse conditions. Periodically, the strains were transferred to seedlings of the same plant species, by mechanical inoculation.

The PRSV-W strain inocula were obtained from young leaves of zucchini squash plants (15 days after inoculation), macerated with pestle in a porcelain mortar, in a $0.02 \mathrm{~mol} \mathrm{~L}^{-1}$ phosphate buffer at $\mathrm{pH} 7.0$, with sodium sulfite at the same molarity, at a proportion of 1:20 (w/ v). The mechanical inoculations were done on the cotyledonary leaves of test-plants, previously dusted with silicon carbide.

\section{PTA-ELISA}

The PTA ("Plate Trapped Antigen") type ELISA ("Enzyme Linked Immunosorbent Assay"), with some modifications as described by Mowat \& Dawson (1987), was performed with the use of polyclonal antiserum against PRSV-W. The volume of reagents at each stage of the test was $100 \mu \mathrm{L}$ per plate cell. Samples were submitted to an incubation time of 16 hours at $5^{\circ} \mathrm{C}$. A 2-hour incubation time at $37^{\circ} \mathrm{C}$ was utilized for the other stages. The absorbance values were obtained 30 minutes after adding the substrate, incubated at room temperature, in a Metertech $\Sigma 960$ ELISA reader, using a $405 \mathrm{~nm}$ filter.

\section{Concentration assessment of mild and severe PRSV- $W$ strains in the test-plants}

The 'Caserta' zucchini squash, 'Menina Brasileira' long-neck squash and 'Crimson Sweet' watermelon plants, at the cotyledonary stage, were submitted to the following treatments: plants inoculated with strain 
PRSV-W-1; plants inoculated with strain PRSV-W-2; plants inoculated with strain PRSV-W-3; plants inoculated with strain PRSV-W-C, and plants inoculated only with the buffer (control). The experimental design was completely randomized, with seven replicates. Each plot consisted of one plant. Three leaf discs $0.8 \mathrm{~cm}$ in diameter were collected at 7, 14, 21, 28 and 35 days after inoculation (DAI) from the first semi-unfolded leaf below the leader shoot of each test-plant; two discs were collected at the base, and one at the tip of the leaves. The same test-plants were utilized during the entire experiment, in such a way that at every $7^{\text {th }}$ DAI, a new semiunfolded leaf was utilized for disc collection. Discs were macerated and diluted 1:20 (w/v) in PBS buffer and stored at $-20^{\circ} \mathrm{C}$ in $1.5 \mathrm{~mL}$ tubes, until the last collection date. All samples were analyzed at the same time 35 DAI by PTA-ELISA, which allows the relative concentration of the virus to be evaluated in the plant extract based on the absorbance values. The absorbance readings from extracts of infected plants were considered positive when values exceeded two times the average of those obtained for the healthy control (Sutula et al., 1986).

\section{Symptomatology and biomass evaluation of plants in- fected with PRSV-W strains}

The severity of symptoms caused by the mild and severe PRSV-W strains in the test-plants was evaluated at 40 DAI. Rating 1 was assigned to plants without mosaic symptoms and leaf deformations and with good development; rating 5 was assigned to those exhibiting mo- saic symptoms, blisters, severe leaf deformations and plant stunting; ratings 2, 3 and 4 were assigned to intermediate symptoms between the two extremes (Rezende \& Pacheco, 1998).

The biomass evaluation in the aerial part of the test-plants was performed at $40 \mathrm{DAI}$. The plants were cut at the root collar and then individually weighed in a semianalytical balance. They were then placed in $10 \mathrm{~kg}$ capacity paper bags, and stored in an oven at $50^{\circ} \mathrm{C}$ for 10 days. Dry mass was obtained by weighing plants using the same balance.

\section{Statistical analysis}

The SAS (Statistical Analysis System) statistical software version 6.11 (SAS, 1990) was utilized, with the application of the Tukey test at 5\% after the $\mathrm{F}$ test in the analysis of variance (Gomes, 1990) for a comparative analysis of the mean absorbance and biomass values in the test-plants.

\section{RESULTS AND DISCUSSION}

\section{Concentration of mild and severe PRSV-W strains in the test-plants}

The absorbance values of extracts from tissues of zucchini squash, long-neck squash and watermelon infected by mild and severe PRSV-W strains, obtained in the PTA-ELISA tests, are presented in Tables 1, 2 and 3, respectively. The results refer to experiments I and II. Two aspects draw attention in the comparative study of con-

Table 1 - Mean PTA-ELISA absorbance values, from extracts of healthy 'Caserta' zucchini squash and plants infected by mild (PRSV-W-1, PRSV-W-2 and PRSV-W-3) and severe (PRSV-W-C) virus strains, on different days after inoculation (DAI), for two independent experiments.

\begin{tabular}{|c|c|c|c|c|c|}
\hline \multirow[b]{2}{*}{ Treatment } & \multicolumn{5}{|c|}{ DAI } \\
\hline & 7 & 14 & 21 & 28 & 35 \\
\hline \multicolumn{6}{|l|}{ Experiment I } \\
\hline HEALTHY & $0.061 \mathrm{c}^{\#}$ & $0.065 \mathrm{c}$ & $0.065 \mathrm{c}$ & $0.062 \mathrm{~b}$ & $0.068 \mathrm{~b}$ \\
\hline PRSV-W-1 & $0.298 \mathrm{~b}$ & $0.195 \mathrm{~b}$ & $0.207 \mathrm{~b}$ & $0.072 \mathrm{~b}$ & $0.067 \mathrm{~b}$ \\
\hline PRSV-W-2 & $0.339 \mathrm{~b}$ & $0.214 \mathrm{~b}$ & $0.253 \mathrm{~b}$ & $0.090 \mathrm{~b}$ & $0.057 \mathrm{~b}$ \\
\hline PRSV-W-3 & $0.366 \mathrm{~b}$ & $0.233 \mathrm{~b}$ & $0.274 \mathrm{~b}$ & $0.099 \mathrm{~b}$ & $0.058 \mathrm{~b}$ \\
\hline PRSV-W-C & $0.440 \mathrm{a}$ & $0.613 \mathrm{a}$ & $0.540 \mathrm{a}$ & $0.225 \mathrm{a}$ & $0.096 \mathrm{a}$ \\
\hline C.V. (\%) & 18.4 & 19.5 & 25.4 & 40.7 & 21.3 \\
\hline \multicolumn{6}{|l|}{ Experiment II } \\
\hline HEALTHY & $0.091 \mathrm{a}$ & $0.103 \mathrm{c}$ & $0.099 \mathrm{~b}$ & $0.102 \mathrm{c}$ & $0.095 \mathrm{c}$ \\
\hline PRSV-W-1 & $0.082 \mathrm{a}$ & $0.327 \mathrm{~b}$ & $0.459 \mathrm{a}$ & $0.248 \mathrm{~b}$ & $0.170 \mathrm{bc}$ \\
\hline PRSV-W-2 & $0.085 \mathrm{a}$ & $0.387 \mathrm{~b}$ & $0.452 \mathrm{a}$ & $0.247 \mathrm{~b}$ & $0.230 \mathrm{~b}$ \\
\hline PRSV-W-3 & $0.096 \mathrm{a}$ & $0.382 \mathrm{~b}$ & $0.482 \mathrm{a}$ & $0.208 \mathrm{bc}$ & $0.213 \mathrm{~b}$ \\
\hline PRSV-W-C & $0.091 \mathrm{a}$ & $0.483 \mathrm{a}$ & $0.541 \mathrm{a}$ & $0.507 \mathrm{a}$ & $0.407 \mathrm{a}$ \\
\hline C.V. (\%) & 12.7 & 17.4 & 21.2 & 25.9 & 23.8 \\
\hline
\end{tabular}

${ }^{\#}$ Columns with distinct letters, between treatments in each experiment, are different at the $5 \%$ level by Tukey test.

C.V. = coefficient of variation. 
Table 2 - Mean PTA-ELISA absorbance values from extracts of healthy 'Menina Brasileira' long-neck squash plants and plants infected by mild (PRSV-W-1, PRSV-W-2 and PRSV-W-3) and severe (PRSV-W-C) virus strains, on different days after inoculation (DAI), for two independent experiments.

\begin{tabular}{|c|c|c|c|c|c|}
\hline \multirow[b]{2}{*}{ Treatment } & \multicolumn{5}{|c|}{ DAI } \\
\hline & 7 & 14 & 21 & 28 & 35 \\
\hline \multicolumn{6}{|l|}{ Experiment I } \\
\hline HEALTHY & $0.057 \mathrm{~d}^{\#}$ & $0.060 \mathrm{c}$ & $0.054 \mathrm{~b}$ & $0.070 \mathrm{a}$ & $0.073 \mathrm{a}$ \\
\hline PRSV-W-1 & $0.117 \mathrm{c}$ & $0.155 \mathrm{bc}$ & $0.079 \mathrm{~b}$ & $0.077 \mathrm{a}$ & $0.069 \mathrm{a}$ \\
\hline PRSV-W-2 & $0.176 \mathrm{~b}$ & $0.201 \mathrm{~b}$ & $0.083 \mathrm{~b}$ & $0.072 \mathrm{a}$ & $0.076 \mathrm{a}$ \\
\hline PRSV-W-3 & $0.273 \mathrm{a}$ & $0.224 \mathrm{~b}$ & $0.068 \mathrm{~b}$ & $0.078 \mathrm{a}$ & $0.065 \mathrm{a}$ \\
\hline PRSV-W-C & $0.176 \mathrm{~b}$ & $0.521 \mathrm{a}$ & $0.135 \mathrm{a}$ & $0.082 \mathrm{a}$ & $0.078 \mathrm{a}$ \\
\hline C.V. (\%) & 40.3 & 32.1 & 33.3 & 17.3 & 7.6 \\
\hline \multicolumn{6}{|l|}{ Experiment II } \\
\hline HEALTHY & $0.064 \mathrm{~b}$ & $0.082 \mathrm{~b}$ & $0.061 \mathrm{~b}$ & $0.061 \mathrm{c}$ & $0.049 \mathrm{c}$ \\
\hline PRSV-W-1 & $0.096 \mathrm{a}$ & $0.161 \mathrm{a}$ & $0.200 \mathrm{a}$ & $0.173 \mathrm{~b}$ & $0.174 \mathrm{ab}$ \\
\hline PRSV-W-2 & $0.083 \mathrm{a}$ & $0.198 \mathrm{a}$ & $0.197 \mathrm{a}$ & $0.187 \mathrm{ab}$ & $0.153 \mathrm{~b}$ \\
\hline PRSV-W-3 & $0.101 \mathrm{a}$ & $0.202 \mathrm{a}$ & $0.217 \mathrm{a}$ & $0.178 \mathrm{~b}$ & $0.144 \mathrm{~b}$ \\
\hline PRSV-W-C & $0.110 \mathrm{a}$ & $0.214 \mathrm{a}$ & $0.288 \mathrm{a}$ & $0.227 \mathrm{a}$ & $0.229 \mathrm{a}$ \\
\hline C.V. (\%) & 16.3 & 29.2 & 28.1 & 13.8 & 19.2 \\
\hline
\end{tabular}

\#Columns with distinct letters, between treatments in each experiment, are different at the 5\% level by Tukey test.

C.V. = coefficient of variation.

Table 3 - Mean PTA-ELISA absorbance values from extracts of healthy 'Crimson Sweet' watermelon plants and plants infected by mild (PRSV-W-1, PRSV-W-2 and PRSV-W-3) and severe (PRSV-W-C) virus strains, on different days after inoculation (DAI), for two independent experiments.

\begin{tabular}{|c|c|c|c|c|c|}
\hline \multirow[b]{2}{*}{ Treatment } & \multicolumn{5}{|c|}{ DAI } \\
\hline & 7 & 14 & 21 & 28 & 35 \\
\hline \multicolumn{6}{|l|}{ Experiment I } \\
\hline HEALTHY & $0.071 \mathrm{c}^{\#}$ & $0.067 \mathrm{c}$ & $0.078 \mathrm{c}$ & $0.084 \mathrm{~b}$ & $0.093 \mathrm{~b}$ \\
\hline PRSV-W-1 & $0.386 \mathrm{~b}$ & $0.202 \mathrm{~b}$ & $0.228 \mathrm{~b}$ & $0.272 \mathrm{~b}$ & $0.152 \mathrm{~b}$ \\
\hline PRSV-W-2 & $0.390 \mathrm{~b}$ & $0.272 \mathrm{~b}$ & $0.161 \mathrm{bc}$ & $0.158 \mathrm{~b}$ & $0.141 \mathrm{~b}$ \\
\hline PRSV-W-3 & $0.376 \mathrm{~b}$ & $0.211 \mathrm{~b}$ & $0.150 \mathrm{bc}$ & $0.161 \mathrm{~b}$ & $0.117 \mathrm{~b}$ \\
\hline PRSV-W-C & $0.583 \mathrm{a}$ & $0.558 \mathrm{a}$ & $0.342 \mathrm{a}$ & $0.414 \mathrm{a}$ & $0.338 \mathrm{a}$ \\
\hline C.V. $(\%)$ & 14.2 & 18.3 & 29.1 & 27.7 & 25.7 \\
\hline \multicolumn{6}{|l|}{ Experiment II } \\
\hline HEALTHY & $0.074 \mathrm{a}$ & $0.082 \mathrm{c}$ & $0.071 \mathrm{c}$ & $0.075 \mathrm{~d}$ & $0.072 \mathrm{c}$ \\
\hline PRSV-W-1 & $0.078 \mathrm{a}$ & $0.399 \mathrm{~b}$ & $0.308 \mathrm{~b}$ & $0.266 \mathrm{c}$ & $0.277 \mathrm{~b}$ \\
\hline PRSV-W-2 & $0.077 \mathrm{a}$ & $0.439 \mathrm{ab}$ & $0.334 \mathrm{~b}$ & $0.341 \mathrm{~b}$ & $0.340 \mathrm{~b}$ \\
\hline PRSV-W-3 & $0.093 \mathrm{a}$ & $0.399 \mathrm{~b}$ & $0.300 \mathrm{~b}$ & $0.348 \mathrm{~b}$ & $0.335 \mathrm{~b}$ \\
\hline PRSV-W-C & $0.083 \mathrm{a}$ & $0.521 \mathrm{a}$ & $0.531 \mathrm{a}$ & $0.571 \mathrm{a}$ & $0.455 \mathrm{a}$ \\
\hline C.V. (\%) & 17.5 & 18.2 & 16.3 & 25.2 & 12.2 \\
\hline
\end{tabular}

\#Columns with distinct letters, between treatments in each experiment, are different at the $5 \%$ level by Tukey test.

C.V. = coefficient of variation .

centrations of mild and severe PRSV-W strains in zucchini squash, long-neck squash and watermelon plants, evaluated based on their absorbance values. These are the progression of concentration as a function of time after inoculation and of the experimental season, and the quantitative differences between mild and severe strains as a function of species. In a general way, experiment I, the three species allowed a fast multiplication of the mild and severe strains, so that significant concentrations were detected as soon as 7 DAI. Three weeks later (28 DAI), the concentrations of the different strains were drastically reduced, and were not detected by the PTA-ELISA test, es- 
pecially in 'Caserta' zucchini squash and 'Menina Brasileira' long-neck squash. The severe strain in zucchini squash was an exception, because only 35 DAI its concentration failed to be detected. In watermelon, the concentration decrease of the mild strains was more conspicuous at 35 DAI. For experiment II, significant concentrations of the mild and severe strains were only detected for the three species starting on 14 DAI. This variation in the progression of concentrations of PRSV-W strains in each species, between experiments I and II, could be directly related to environmental conditions imposed by the greenhouse. Among the environmental variables, temperature was probably the factor that more strongly influenced the replication progression of PRSV$\mathrm{W}$ strains in the three cucurbit species. The occurrence of concentration peaks of PRSV-W strains as soon as 7 DAI in experiment I could be associated to higher temperatures in general and longer days that prevail in January and February; this could have accelerated test-plant development, resulting in faster virus strain replication. Lower temperatures and shorter days, on the other hand, which are typical of June and July, could have delayed test-plant development in experiment II, and influenced virus concentration peaks, which occurred after 14 DAI. This effect of temperature on virus concentration peaks corroborates papers by Bancroft \& Pound (1956) with Tobacco mosaic virus in tobacco and tomato, and by Cheo \& Pound (1952) with Cucumber virus 1 in spinach; these authors observed virus concentration peaks on the initial days of infection in plants exposed to higher temperatures and later peaks in plants exposed to lower temperatures.

In addition to changing the length of time necessary for greater virus accumulation to occur in the plants, temperature can also affect the amount of virus. This fact has been reported by Pound \& Helms (1955) with Potato virus $X$ in tobacco, by Bancroft (1958) for Squash mosaic virus in long-neck squash and zucchini squash, by Foster \& Webb (1965) for five cucurbit viruses, among which the PRSV-W (WMV-1), and by Dahal et al. (1998) for Banana streak badnavirus in banana. In all these cases it was verified that lower temperatures favored greater virus accumulation in the test-plants. In the present study, however, no differences were observed in the concentrations of different PRSV-W strains as a function of the experimental season, probably because temperature differences between the two experiments were not as prominent as those prevailing in the experiments from these investigators, who worked under controlled temperature environments.

The second important aspect was a smaller concentration of mild strains PRSV-W-1, PRSV-W-2 and PRSV-W-3, as compared to the severe strain, especially for zucchini squash and watermelon plants (Tables 1 and 3). Banik \& Zitter (1990), working with mild and severe CMV strains and their effect on the transmissibility by vectors, verified that the severe strain had higher concentration in melon plants (Cucumis melo L.) and greater transmission rate by aphids. As for 'Menina Brasileira' long-neck squash, differences between mild and severe strain concentrations were, in general, less prominent than those observed for the other two species (Table 2). Furthermore, the severe PRSV-W strain also attained much lower concentrations than those verified for 'Caserta' zucchini squash and 'Crimson Sweet' watermelon (Tables 1, 2 and 3). This lower virus concentration might be associated to the apparent resistance to PRSV-W replication shown by 'Menina Brasileira' long-neck squash.

\section{Symptomatology and biomass in the aerial part of test- plants}

The rate of plant infection by the different strains, for both experiments, was $100 \%$ (Table 4). The 'Caserta' zucchini squash and 'Crimson Sweet' watermelon infected plants presented similar behavior among themselves with respect to the severity of the symptoms caused by the severe PRSV-W strain (rating 5). In turn, the 'Menina Brasileira' long-neck squash plants presented relatively mild mosaic symptoms, without leaf deformations (rating 2), when infected by the severe virus strain. The zucchini squash, long-neck squash and watermelon plants did not show mosaic symptoms when infected with the three mild PRSV-W strains (rating 1), 40 DAI (Table 4, Figures 1, 2 and 3).

In 'Caserta', plants infected with mild strains PRSV-W-1, PRSV-W-2 and PRSV-W-3 had their biomass slightly reduced and, in some cases, statistically distinct from those of healthy plants (Table 5). Based on the means for fresh mass of plants infected by the mild strains and for fresh mass of plants infected by the severe strain and comparing them with values for healthy plants, it was verified, for experiment I, that the mild and severe strains caused reductions of $8.9 \%$ and $29 \%$, respectively, in the biomass of 'Caserta' plants. For experiment II, however, reductions of $12.4 \%$ and $33.8 \%$ were observed for the biomass of plants infected by the mild and severe strains, respectively.

The biomass of 'Menina Brasileira' long-neck squash plants infected by the mild and severe strains, for experiments I and II, did not differ statistically from those obtained for healthy plants. For experiment I, the mild strains caused a biomass reduction of the order of $0.3 \%$. The plants infected by the severe strain had a biomass $4.9 \%$ higher than healthy plants. For experiment II, the biomasses of plants infected by the mild and severe strains were $19.2 \%$ and $7.2 \%$ higher than those of healthy plants, respectively.

Additionally, the biomass values for 'Crimson Sweet' watermelon plants infected by mild strains were not different from those values obtained for healthy plants, in both experiments. Plants infected by the severe strain 
Table 4 - Frequency of 'Caserta' zucchini squash, 'Menina Brasileira' long-neck squash and 'Crimson Sweet' watermelon plants infected by mild (PRSV-W-1, PRSV-W-2 and PRSV-W-3) and severe (PRSV-W-C) virus strains as a function of ratings for leaf symptom severity at 40 days after inoculation.

\begin{tabular}{|c|c|c|c|c|c|c|}
\hline \multirow[b]{2}{*}{ Treatments } & \multirow[b]{2}{*}{$\begin{array}{c}\text { No. of inoculated } \\
\text { plants* }\end{array}$} & \multicolumn{5}{|c|}{ No. of plants in relation to symptom severity ratings } \\
\hline & & $1 * *$ & 2 & 3 & 4 & 5 \\
\hline \multicolumn{7}{|c|}{ 'Caserta' zucchini squash } \\
\hline PRSV-W-1 & 14 & 14 & - & - & - & - \\
\hline PRSV-W-2 & 14 & 14 & - & - & - & - \\
\hline PRSV-W-3 & 14 & 14 & - & - & - & - \\
\hline PRSV-W-C & 14 & - & - & - & - & 14 \\
\hline \multicolumn{7}{|c|}{ 'Menina Brasileira' long-neck squash } \\
\hline PRSV-W-1 & 14 & 14 & - & - & - & - \\
\hline PRSV-W-2 & 14 & 14 & - & - & - & - \\
\hline PRSV-W-3 & 14 & 14 & - & - & - & - \\
\hline PRSV-W-C & 14 & - & 14 & - & - & - \\
\hline \multicolumn{7}{|c|}{ 'Crimson Sweet' watermelon } \\
\hline PRSV-W-1 & 14 & 14 & - & - & - & - \\
\hline PRSV-W-2 & 14 & 14 & - & - & - & - \\
\hline PRSV-W-3 & 14 & 14 & - & - & - & - \\
\hline PRSV-W-C & 12 & - & - & - & - & 12 \\
\hline
\end{tabular}

*Total of plants in both experiments.

${ }^{* *} 1=$ no symptoms through $5=$ severe mosaic with blisters, severe leaf deformation and plant stunting.

Table 5 - Fresh (FM) and dry mass (DM) means for the aerial part of healthy 'Caserta' zucchini squash, 'Menina Brasileira' long-neck squash and 'Crimson Sweet' watermelon plants and plants infected by mild (PRSV-W-1, PRSV-W-2 and PRSV-W-3) and severe (PRSV-W-C) virus strains, 40 days after infection, for two independent experiments.

\begin{tabular}{|c|c|c|c|c|c|c|}
\hline \multirow[b]{2}{*}{ Treatment } & \multicolumn{2}{|c|}{$\begin{array}{l}\text { Zucchini squash cv. } \\
\text { Caserta }\end{array}$} & \multicolumn{2}{|c|}{$\begin{array}{c}\text { Long-neck squash cv. } \\
\text { Menina Brasileira }\end{array}$} & \multicolumn{2}{|c|}{$\begin{array}{l}\text { Watermelon cv. } \\
\text { Crimson Sweet }\end{array}$} \\
\hline & FM & $\mathrm{DM}$ & FM & $\mathrm{DM}$ & FM & $\mathrm{DM}$ \\
\hline \multicolumn{7}{|l|}{ Experiment I } \\
\hline HEALTHY & $257.5 \mathrm{a}^{\#}$ & $28.6 \mathrm{ab}$ & $345.2 \mathrm{a}$ & $30.5 \mathrm{a}$ & $222.3 \mathrm{a}$ & $23.3 \mathrm{a}$ \\
\hline PRS V-W-1 & $210.4 \mathrm{ab}$ & $22.1 \mathrm{~b}$ & $331.0 \mathrm{a}$ & $30.2 \mathrm{a}$ & $217.5 \mathrm{a}$ & $20.6 \mathrm{a}$ \\
\hline PRSV-W-2 & $243.2 \mathrm{a}$ & $27.6 \mathrm{ab}$ & $347.2 \mathrm{a}$ & $32.1 \mathrm{a}$ & $223.3 \mathrm{a}$ & $22.3 \mathrm{a}$ \\
\hline PRSV-W-3 & $249.7 \mathrm{a}$ & $30.2 \mathrm{a}$ & $354.0 \mathrm{a}$ & $32.6 \mathrm{a}$ & $215.0 \mathrm{a}$ & $21.4 \mathrm{a}$ \\
\hline PRSV-W-C & $182.7 \mathrm{~b}$ & $17.3 \mathrm{c}$ & $362.3 \mathrm{a}$ & $36.8 \mathrm{a}$ & $105.4 \mathrm{~b}$ & $10.7 \mathrm{~b}$ \\
\hline C.V. $(\%)$ & 14.0 & 17.7 & 10.5 & 14.1 & 20.6 & 24.4 \\
\hline \multicolumn{7}{|l|}{ Experiment II } \\
\hline HEALTHY & $295.6 \mathrm{a}$ & $36.5 \mathrm{a}$ & $154.7 \mathrm{a}$ & $12.5 \mathrm{a}$ & $164.2 \mathrm{a}$ & $14.1 \mathrm{a}$ \\
\hline PRSV-W-1 & $263.5 \mathrm{ab}$ & $26.9 \mathrm{~b}$ & $172.0 \mathrm{a}$ & $13.1 \mathrm{a}$ & $149.8 \mathrm{a}$ & $11.6 \mathrm{a}$ \\
\hline PRS V-W-2 & $231.2 \mathrm{~b}$ & $22.4 \mathrm{~b}$ & $177.8 \mathrm{a}$ & $14.8 \mathrm{a}$ & $164.4 \mathrm{a}$ & $13.8 \mathrm{a}$ \\
\hline PRSV-W-3 & $282.1 \mathrm{ab}$ & $24.4 \mathrm{~b}$ & $203.5 \mathrm{a}$ & $17.0 \mathrm{a}$ & $139.9 \mathrm{a}$ & $12.6 \mathrm{a}$ \\
\hline PRSV-W-C & $195.5 \mathrm{c}$ & $14.8 \mathrm{c}$ & $165.8 \mathrm{a}$ & $13.5 \mathrm{a}$ & $42.4 \mathrm{~b}$ & $3.8 \mathrm{~b}$ \\
\hline C.V. $(\%)$ & 15.2 & 22.1 & 18.4 & 23.6 & 32.5 & 41.1 \\
\hline
\end{tabular}

${ }^{\#}$ Columns with distinct letters, between treatments in each experiment, are different at the $5 \%$ level by Tukey test.

C.V. = coefficient of variation.

had biomass values statistically distinct from the other treatments. For experiment I, plants infected by the mild strains presented a biomass reduction of the order of 1.7 $\%$ as compared to healthy plants. For plants infected by the severe strain there was a $52.6 \%$ biomass reduction rela- tive to healthy plants. For experiment II, the mild and severe strains caused reductions of the order of $7.8 \%$ and $74.2 \%$, respectively, in relation to plant biomass.

It was observed, in general, for biomass and symptomatology evaluations, that infection by the severe 


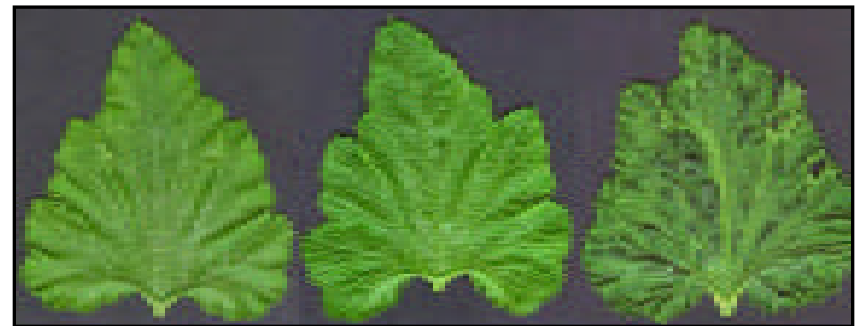

Figure 1 - Healthy 'Caserta' zucchini squash leaf (left), leaf infected with mild PRSV-W-1 (center) and severe PRSV-W-C (right) virus strains, 40 days after infection.

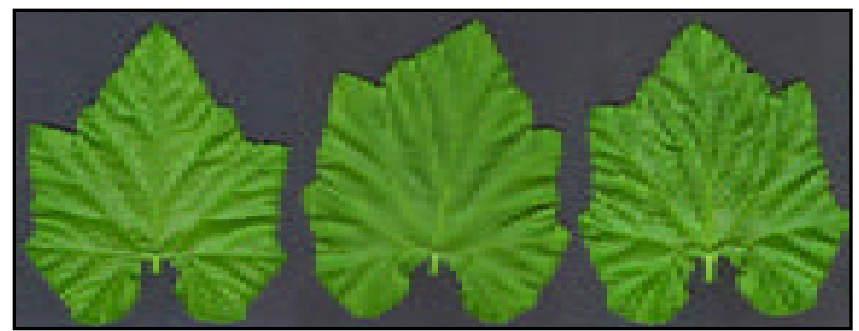

Figure 2 - Healthy 'Menina Brasileira' long-neck squash leaf (left), leaf infected with mild PRSV-W-1 (center) and severe PRSV-W-C (right) virus strains, 40 days after infection.

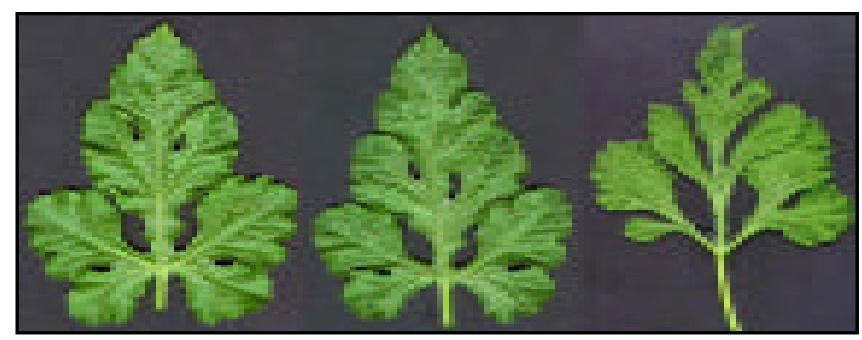

Figure 3 - Healthy 'Crimson Sweet' watermelon leaf (left), leaf infected with mild PRSV-W-1 (center) and severe PRSV-W-C (right) virus strains, 40 days after infection.

PRSV-W-C strain affected the phenotype and development of zucchini squash and watermelon plants. On the other hand, only a slight reduction of biomass was observed for plants of these species when they were infected by mild strains PRSV-W-1, PRSV-W-2 and PRSV-W-3. In this case, the reduction in biomass was approximately $10 \%$. Field experiments have reported reductions of the order of $10 \%$ as well, in total fruit yield of 'Caserta' zucchini squash and hybrid Tetsukabuto-type long-neck squash plants pre-immunized with strains PRSV-W-1 and PRSV-W-2 (Dias \& Rezende, 2000; Rezende \& Pacheco, 1998). Other authors have also reported yield decreases between $11 \%$ and $15 \%$ in plants pre-immunized by mild strains of other viruses, as Lecoq et al. (1991) with ZYMV for zucchini squash and Montasser et al. (1998) with CMV in melon.

No significant damage was observed for phenotype, fresh and dry mass for 'Menina Brasileira' longneck squash infected by the mild and severe PRSV-W strains. This is probably due to the known tolerance of 'Menina Brasileira' long-neck squash to PRSV-W-caused mosaic (Kuabara et al., 1987). Even though not significantly affecting its phenotype and biomass, the tolerance of 'Menina Brasileira' long-neck squash to mosaic could be correlated to its apparent resistance against PRSV-W replication, in spite that virus concentration is not always directly related to disease tolerance (Cooper \& Jones, 1983). Lapidot et al. (1997) did not find correlation between tolerance of green pepper plants to CMV-caused mosaic and virus concentration in the plants. The same has been reported by Anderson et al. (1996), in a study on cowpea tolerance to Blackeye cowpea mosaic virus and to CMV.

\section{REFERENCES}

ANDERSON, E.J.; KLINE, A.S.; MORELOCK, T.E.; McNEW, R.W. Tolerance to blackeye cowpea mosaic potyvirus not correlated with decreased virus accumulation or protection from cowpea stunt disease. Plant Disease, v.80, p.847-852, 1996.

BANCROFT, J.B. Temperature and temperature light effects on the concentration of squash mosaic virus in leaves of growing cucurbits. Phytopathology, v.48, p.98-102, 1958.

BANCROFT, J.B.; POUND, G.S. Cumulative concentrations of tobacco mosaic virus in tobacco and tomato at different temperatures. Virology, v.2, p.29-43, 1956.

BANIK, M.T.; ZITTER, T.A. Determination of cucumber mosaic virus titer in muskmelon by enzyme-linked immunosorbent assay and correlation with aphid transmisson. Plant Disease, v.74, p.857-859, 1990.

CHEO, PC.; POUND, G.S. Relation of air temperature, soil temperature, photoperiod, and light intensity to the concentration of cucumber virus 1 in spinach. Phytopathology, v.42, p.306-310, 1952.

COOPER, J.I.; JONES, A.T. Responses of plants to viruses: proposals for the use of terms. Phytopathology, v.73, p.127-128, 1983.

DAHAL, G.; HUGHES, J. d'A.; THOTTAPPILLY, G. Effect of temperature on symptom expression and reliability of banana streak badnavirus detection in naturally infected plantain and banana (Musa spp.). Plant Disease, v.82, p.16-21, 1998.

DIAS, P.R.P.; REZENDE, J.A.M. Premunização da abóbora híbrida Tetsukabuto para o controle do mosaico causado pelo Papaya rigspot virus - type W. Summa Phytopathologica, v.26, p.390-398, 2000.

FOSTER, R.E; WEBB, R.E. Temperature effects on symptom expression and concentration of six muskmelon viruses. Phytopathology, v.55, p.981-985, 1965.

GOMES, F.D. Curso de estatística experimental. 13.ed. Piracicaba: Nobel, 1990. 468p.

KUABARA, M.Y.; SALCEDO, M.J.G.; COSTA, C.P. Fontes de resistência ao vírus do mosaico da melancia (WMV-1) em abóbora. Horticultura Brasileira, v.5, p.20-21, 1987.

LAPIDOT, M.; PARAN, I.; BAR-JOSEPH, R.; BEN-HARUSH, S.; PILOWSKY, M.; COHEN, S.; SHIFRISS, C. Tolerance to cucumber mosaic virus in pepper: development of advanced breeding lines and evaluation of virus level. Plant Disease, v.81, p.185-188, 1997.

LECOQ, H.; LEMAIRE, J.M; WIPF-SCHEIBEL, C. Control of zucchini yellow mosaic virus in squash by cross protection. Plant Disease, v.75, p.208-211, 1991.

MONTASSER, M.S.; TOUSIGNANT, M.E.; KAPER, J.M. Virus satellite RNAs for the prevention of cucumber mosaic virus (CMV) disease in field-grown pepper and melon plants. Plant Disease, v.82, p.1298-1303, 1998.

MOWAT, W.P.; DAWSON, S. Detection and identification of plant viruses by ELISA using crude sap extracts and unfractioned antisera. Journal of Virological Methods, v.15, p.233-247, 1987.

POUND, G.S.; HELMS, K. Effects of temperature on multiplication of potato virus X in nicotiana species. Phytopathology, v.45, p.493-499, 1955.

PURCIFULL, D.; EDWARSON, J.; HIEBERT, E.; GONSALVES, D. Papaya ringspot virus. CMI/AAB. Description of Plant Viruses, n.292, p. $1-8,1984$ 
REZENDE, J.A.M.; PACHECO, D.A. Control of papaya ringspot virustype $\mathrm{W}$ in zucchini squash by cross-protection in Brazil. Plant Disease, v.82, p.171-175, 1998.

REZENDE, J.A.M.; PACHECO, D.A.; IEMMA, A.F. Efeitos da premunização da abóbora 'Menina Brasileira' com estirpes fracas do vírus do mosaico do mamoeiro estirpe-melancia. Pesquisa Agropecuária Brasileira, v.34, p.1481-1489, 1999.

REZENDE, J.A.M.; YUKI, V.A.; VEGA, J.; SCAGLIUSI, S.M.M.; BORBA, L.F.; COSTA, A.S. Estirpes fracas do potyvirus causador do mosaico da abobrinha presentes em bolhas atuam na premunização. Fitopatologia Brasileira, v.18, p.55-61, 1994.

SAS Institute. SAS / STAT user's guide. 4.ed. Cary: Statistical Analysis System Institute, 1990. 943p
SUTULA, C.L.; GILLETT, J.M.; MORRISSEY, S.M.; RAMSDELL, D.C. Interpreting ELISA data and establishing the positive-negative threshold. Plant Disease, v.70, p.722-726, 1986.

YUKI, V.A. Epidemiologia e controle do mosaico (VMM-Me) em abobrinhade-moita. Piracicaba: USP/ESALQ, 1990. 84p. (Tese - Doutorado)

Received March 21, 2002

Accepted July 21, 2003 